
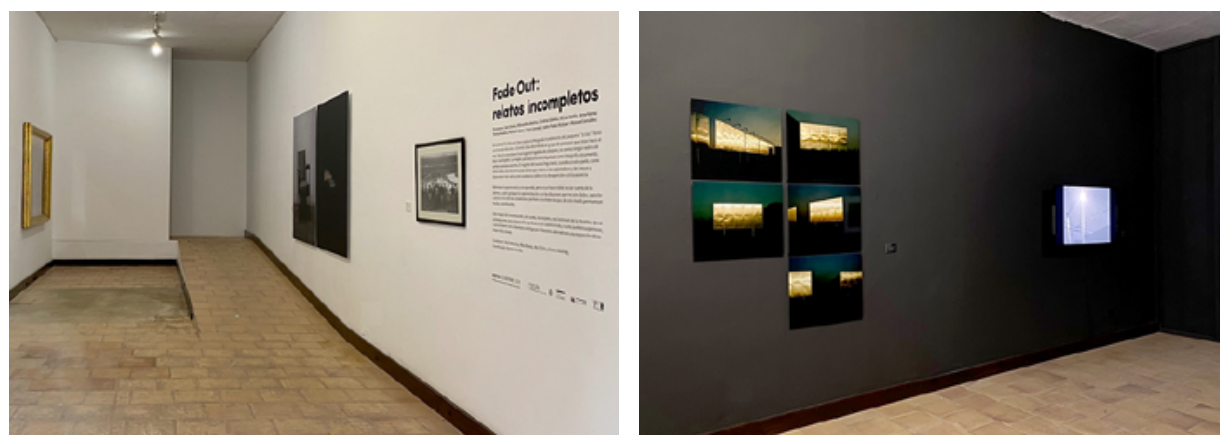

\title{
FADE OUT: RELATOS INCOMPLETOS
}

\author{
Ramiro Carrillo \\ Sala La Cochera, Güímar \\ Bienal Internacional de Fotografía Fotonoviembre. \\ Noviembre de 2021, Tenerife
}

En un momento en que el comisariado tiende a verse como una forma de arte, atravesada también por individualismos y egolatrías, resulta estimulante asistir a un proyecto surgido de un comisariado colaborativo e intersubjetivo.

Fade out: relatos incompletos fue el resultado de una colaboración entre la Bienal de Fotografía Fotonoviembre (Tenerife, 2021) y la Facultad de Bellas Artes de la Universidad de La Laguna. Como docente de la asignatura Crítica de Arte y Curaduría, del Grado en Bellas Artes, recibí el encargo, por parte de Teresa Arozena, comisaria de Fotonoviembre, de coordinar una exposición comisariada por alumnado de la mencionada asignatura. El proceso se inició con la selección de cuatro estudiantes (Inés Arencibia, Mike Batista, Mai Diallo y Emma Martings) que formaron el equipo curatorial, con el reto de trabajar con una metodología que no desembocara en una suma de voces individuales, sino en la creación de una suerte de sujeto colectivo.

Para ello, el equipo abandonó cualquier posición taxativa o beligerante, trabajando con procesos de diálogo y de interinfluencia entre las distintas subjetividades. Así, tras una relativamente corta puesta en común de las posiciones individuales, se decidió proponer una narración fragmentada, hilvanada como una deriva del equipo curatorial a partir de Hundimiento del pesquero "La Isla» frente a la Torre de Hércules. A Coruña (1970), de Manuel López; una fotografía de un grupo de personas 
que miran al mar, escrutando el rastro de un naufragio; es decir, observando algo que ya no está. La imagen activó el interés del equipo por el concepto de desaparición, de desvanecimiento de lo visto, planteado como una grieta en la imagen que abre y expande sus contornos y significados. Con esta idea, se seleccionaron fotografías de Pedro Pablo Alcázar, Carlo Corradi, Cristina Gómez, Manuel González, Anna Kanai, Manuel López, Alicia Martín, Perejaume, y vídeos de Teresa Arozena, Miloushka Bokma y Sara Garsía. Toda esta obra componía, en su conjunto, un paisaje de escenas desocupadas, de protagonistas que se marchan o se desvanecen, de fotografías desenfocadas o veladas, generando un conjunto de imágenes, no vacías, sino vaciadas; que destacaban a la vez por su condición de ausencia y de presencia, demostrando que siempre es la imaginación y el pensamiento de quien observa lo que completa el relato; lo que, en definitiva, termina la fotografía. 